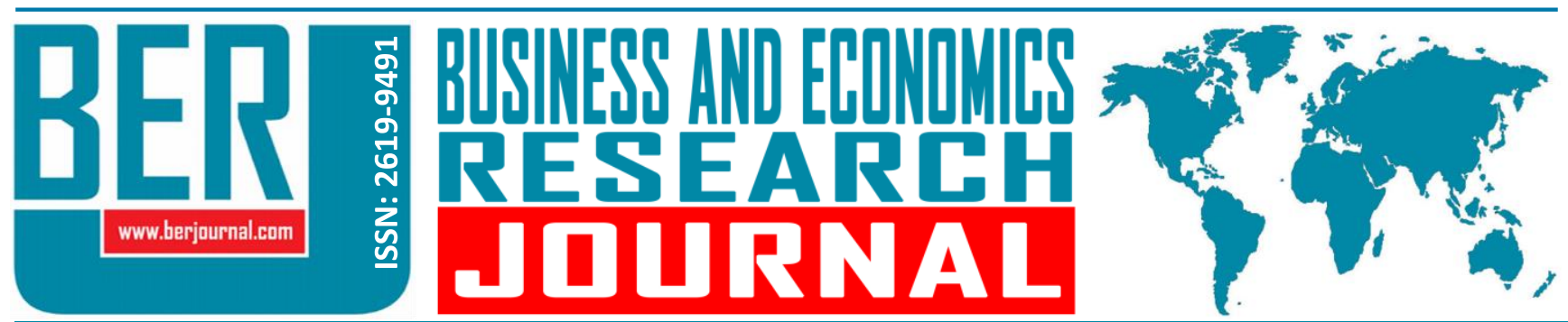

Business and Economics Research Journal Vol. 10, No. 3 Special Issue, 2019, pp. 709-722 doi: 10.20409/berj.2019.195

\title{
Yönetici Dürüstlüğünün Örgütsel Vatandaşlık Davranışına Etkisinde Yöneticiye Duyulan Güvenin Rolü*
}

\section{Ilksun Didem Ulbegi ${ }^{\mathrm{a}}$}

Öz: Bu çalışmanın amacı yöneticinin dürüstlüğ̈̈ne ilişkin çalışanların algıları ile yöneticiye güven ve örgütsel vatandaşlık davranışları arasındaki ilişkileri doğrudan, dolaylı ve toplam etkiler bağlamında ortaya koymaktır. Bu doğrultuda kolayda örnekleme yöntemi kullanılarak Adana ilinde görev yapmakta olan 413 banka çalışanından veri toplanmıştır. Çalışmada öncelikle araştırma kapsamında önerilen ölçüm modelinin geçerliğini ortaya koymak amacıyla doğrulayıcı faktör analizi yapılmış ve modelin çok iyi düzeyde uyum gösterdiği belirilenmiştir. Çalışma kapsamında ölçeklerin güvenirliğini ortaya koymak amacıyla Cronbach Alfa iç tutarlık katsayısı ile bileşik güvenirlik katsayısı ele alınmış ve araştırmada kullanılan ölçeklerin güvenilir olduğu tespit edilmiștir. Ayrıca değişkenler arasındaki ilișkilerin korelasyon analizi kullanılarak istatistiksel olarak anlamlı olduğu ortaya konulmuştur. Ardından araştırma modeli çerçevesinde öne sürülmüss olan hipotezleri test etmek amacıyla yapısal eșitlik modeli ve bootstrap yöntemi kullanılarak değişkenler arasındaki doğrudan, dolaylı ve toplam etkiler ortaya konulmuștur. Araştırmanın bulguları, yöneticinin dürüstlügüne ilişkin algıların çalışanların örgütsel vatandaşlık davranışlarına etkisinin olduğunu göstermekle birlikte bu ilişkide ayrıca yöneticiye duyulan güvenin de kısmi aracılık rolü üstlendiğini ortaya koymaktadır. Çalışma kapsamında elde edilmiş olan bu bulgular alan yazında yapılmış olan çalışmalar çerçevesinde ve kuramsal bağlamda değerlendirilerek tartışılmaktadır.

\section{The Effect of Supervisor Integrity on Employees' Organizational Citizenship Behaviors: The Role of Trust in} Supervisor

Abstract: The aim of this study is to reveal the direct, indirect, and total effects between the supervisor integrity perceptions of employees, trust in supervisor, and organizational citizenship behaviors. In this respect, the data is collected using a convenience sampling method from 413 banking employees working in Adana. To begin with, the confirmatory factor analysis is conducted in order to examine the validity of the proposed model in the study and showed that the model has a very good model fit. In the study, in order to reveal the reliability of the scales, Cronbach Alpha internal consistency coefficient and composite reliability coefficient are used and identified that the scales used in the study are reliable. Moreover, using correlation analysis the relationships between the variables are revealed statistically significant. Subsequently, structural equation modeling and bootstrapping method are used in order to test the proposed hypotheses in the context of the research model and revealed the direct, indirect, and total effects between the variables. In this regard, the model proposed in the research frame established a very good model fit. Study results revealed that the perceptions about the supervisor integrity have an effect on the employees' organizational citizenship behaviors in addition to this there is a partial mediation effect of trust in supervisor in this relationship. These study results are discussed in the context of previously conducted studies and theoretical framework.

Anahtar Sözcükler: Yönetici Dürüstlüğü, Yöneticiye Güven, Örgütsel Vatandaşlık Davranışı, Yapısal Eşitlik Modeli, Aracı Değişken Analizi

JEL: D23, C31, C83

Geliş : : 05 Şubat 2019

Düzeltme : 11 Mart 2019

Kabul : :01 Nisan 2019

Tür : : Araştırma

Keywords: Supervisor Integrity, Trust in Supervisor, Organizational Citizenship Behavior, Structural Equation Modelling, Mediation Analysis

JEL: D23, C31, C83

Received : 05 February 2019

Revised : 11 March 2019

Accepted : 01 April 2019

Type : Research 


\section{Giriş}

Günümüzün küresel ölçekte artan rekabet koşulları, teknolojik ilerlemeler ve çevre şartlarında meydana gelen hızlı değişimler örgütlerin işleyişleri üzerinde etkili olmaktadır. Örgütlerin bu gelişmeler karşısında başarılı bir şekilde faaliyetlerini sürdürebilmelerinde insan kaynağı önemli bir etken olarak karşımıza çıkmaktadır. Yalnızca belirlenmiş olan resmi roller çerçevesinde görevlerin yerine getirildiği bir organizasyon oldukça zayıf bir sosyal yapıya işaret etmektedir (Katz, 1964: 132). Örgütün başarısında özellikle çalışanların biçimsel görev tanımlarının ötesinde çaba sarfetmelerinin etkin bir rol oynadığı bilinmektedir (Organ, 1988). Örgütsel vatandaşıık davranışı (ÖVD) olarak alan yazında yer almış olan bu kavram uluslararası yazında yıllardır araştırılmakta olup (Organ, 1988; ; Organ ve Ryan, 1995; Organ, Podsakoff ve MacKenzie, 2006) benzer olarak ulusal yazında da yoğun ilgi gören bir konu olmaktadır (Örn., Arslantaş, 2008; Yıldız, 2014; Çavuş ve Develi, 2015; Boğan ve Dedeoğlu, 2016). Bu ilginin temelinde ise örgütsel etkinlik, performans, iş tatmini, müşteri tatmini, işten ayrılma niyeti ve devamsızlık (Örn., Organ, Podsakoff ve MacKenzie, 2006; Nielsen, Hrivbak ve Shaw, 2009; Podsakoff, Whiting, Podsakoff ve Blume, 2009; Whitman, Van Rooy ve Viswesvaran, 2010) benzeri çeşitli tutum ve davranışlarını açıklayabilme çabası yer almaktadır.

Örgütsel vatandaşıık davranışının oluşumunda kişilik, adalet algısı, güven, lider davranışları, lider-üye etkileşimi gibi farklı etkenlerin rol oynadığı bilinmektedir (Örn., Organ ve Ryan, 1995; Podsakoff, Mackenzie, Paine ve Bachrach, 2000; Colquitt, Conlon, Wesson, Porter ve Ng, 2001; LePine ve Van Dyne, 2001; Dirks ve Ferrin, 2002; Wat ve Schaffer, 2005; Ilies, Nahrang ve Morgeson, 2007). Ayrıca çalışanların resmi faaliyetleri dışında söz konusu bağlamsal, olumlu sosyal ve rol ötesi davranışlar sergilemeleri yönündeki en önemli faktörler arasında çalışanların lidere ilişkin algıları yer almaktadır (Piccolo, Buengeler ve Judge, 2018).

Lider dürüstlüğünün özellikle çalışanların algı, tutum ve davranışlarına etkisi doğrultusunda önem taşıyan bir kavram olarak karşımıza çıktığı görülmekte olup (Moorman ve Grover, 2009), Simons (2002) dürüstlüğün örgütsel vatandaşlık davranışı üzerinde etkisi olduğunu ileri sürmüştür.

Dürüstlük bireylerin yaşamlarının her alanında vazgeçilmez bir özellik olarak karşımıza çıkmaktadır. Benzer olarak çalışma yaşamında da dürüstlük, işe ilişkin her alanda rol almakta olup, kişisel ve örgütsel başarıda kritik bir öneme sahip (Lennick ve Kiel, 2007; Simons, 2008) temel olarak iyi bir karakter yapısını oluşturan bir erdem olarak nitelendirilebilmektedir (Palanski ve Yammarino, 2007: 172). Dürüstlük, bireyin sözleri ile eylemleri arasındaki algılanan uyum örüntüsünü (Simons, 2002: 19) ifade etmekle birlikte, benimsenmiş ve yürürlükte olan değerlerin uyumu ile vaadedilen sözlerin ne derece yerine getirildiğine ilişkin algı da ön plana çıkmaktadır (Simons, Friedman, Liu ve McLean Parks, 2007).

Çalışanların tutum ve davranışlarını şekillendiren en önemli faktörlerin başında yöneticilerine ilişkin algıları yer almaktadır. Ayrıca çalışanların ÖVD geliştirmelerinde bir diğer önemli unsur yönetciye duyulan güven oalrak karşımıza çıkmaktadır. Simons ve McLean Parks (2000) dürüstlüğün yöneticiye güven ile ilişkili bir kavram olduğunu ortaya koymuşlardır.

Dürüstlüğün çalışma yaşamında önemli bir unsur olmasına karşılık, yönetcilerin dürüstlüğünün çalışanların tutum ve davranışlarına olan etkileri konusunda yaygın olarak araştırmaların bulunmadığı görülmektedir (Sosik, Gentry ve Chun, 2012). Buradan hareketle, bu çalışmada ise yöneticinin dürüstlüğüne yönelik algıları ile çalışanların örgütsel vatandaşık davranışları arasındaki ilişkide lidere olan güvenin önemli bir faktör olduğuna dikkat çekilmektedir. Buna göre yöneticinin ahlâki davranması, dürüst olması ve tutarlı davranışlar sergilemesinin, çalışanların yöneticilerine olan güven düzeylerini etkilemekle birlikte söz konusu bu güven aracılığı ile de çalışanların örgüte ve bireye yönelik örgütsel vatandaşlık davranışları sergilemeleri üzerinde etkileri olacağı tartışılmaktadır.

Bu doğrultuda mevcut araştırma ile yöneticinin dürüstlüğüne ilişkin çalışanların algılamalarının, yöneticiye olan güven ile örgüte yönelik ve bireye yönelik örgütsel vatandaşlık davranışları üzerindeki etkilerinin ortaya koyulması amaçlanmaktadır. Ayrıca yöneticiye olan güven düzeyinin örgütsel vatandaşıı davranışlarına olan etkileri ile birlikte yöneticinin ahlâki davranışları, dürüst olması ve tutarlı davranmasının çalışanların bireye ve örgüte yönelik örgütsel vatandaşlık davranışları göstermelerine etkisinde yöneticiye olan güvenin aracı etkisi ele alınmaktadır. Araştırma kapsamında ortaya konulan model çerçevesinde söz konusu bu ilişkilerin ortaya konulması ve kavramsal bağlamda ele alınmasıyla alan yazına katkı sağlanması beklenmektedir. 


\section{Kavramsal Çerçeve}

Örgütsel vatandaşlık davranışı, resmi ödül sistemi tarafından doğrudan veya açık bir şekilde onaylanmamış ve toplam olarak örgütün etkin biçimde faaliyet göstermesinde katkıda bulunan bireysel davranışlar olarak tanımlanmaktadır (Organ, 1988: 3). Örgütsel vatandaşlık davranışını Organ (1988) yardımseverlik, nezaket, vicdanlılık, centilmenlik ve sivil erdemden oluşan beş boyutlu bir yapıda ortaya koymuş olmakla birlikte, Williams ve Anderson (1991) belirli kişilerin yarar gördüğü ve dolaylı olarak örgütün faydalandığı bireye yönelik örgütsel vatandaşlık davranışı ve genel olarak örgütün avantaj sağladığı örgüte yönelik örgütsel vatandaşılk davranışı olmak üzere iki boyutta ele almıştır.

Örgütsel bağlamda yönetici dürüstlüğü, yöneticilerinin söz ve edimlerinin örtüşmesine ilişkin çalışanların algıları olarak nitelendirilmektedir (Simons, 2002). Algılanan yönetici dürüstlüğü, liderin plan ve vaadleri doğrultusunda dürüst, uygun ve tutarlı davranacağına yönelik çalışanların düşüncelerini içermekte olup (Moorman, Darnold ve Priesemuth, 2013), liderin sözleri ile bunları izleyen eylemlerine ilişkin yararlı bilgi sağlamakta ve aynı zamanda yöneticinin değerleri ve ahlâki anlayışı ile çalışanların kendi değer ve anlayışlarının uyum gösterip göstermediğine yönelik fikir vermektedir (Moorman ve Grover, 2009: 103).

Moorman ve Grover (2009) çalışmalarında algılanan yönetici dürüstlüğünü, yöneticinin sözleri ile hareketlerinin ve aynı zamanda söz konusu bu eylemlerin de liderin ve takipçilerinin ortak paylaşılan değerleri ile uyumlu olarak algılanması olarak kavramsallaştırmışlardır. Buna göre dürüst yönetici benimsediği değerler ile uyumlu olarak davranırken aynı zamanda kendisinin ve takipçilerinin ortak etik ve ahlaki anlayışı bağlamında eylemlerde bulunmaktadır (Moorman ve Grover, 2009).

Örgütsel vatandaşlık davranışının ortaya çıkmasında çeşitli unsurların etkileri söz konusu olabilmektedir (Spitzmuller, Van Dyne ve Ilies, 2008). Yapılan çalışmalar kişiliğin (Örn., Organ ve Ryan, 1995; Podsakoff, vd., 2000; LePine ve Van Dyne, 2001), iş tatmininin (Podsakoff vd., 2000), örgütsel bağlılığın (Organ ve Ryan, 1995), örgütsel adalet algısının (Örn., Podsakoff vd., 2000; Colquitt, vd., 2001), dönüşümcü ve etkileşimci liderlik (Örn., Organ ve Ryan, 1995; Podsakoff vd., 2000), lider üye etkileşiminin (Örn., Ilies, vd., 2007) örgütsel vatandaşlık davranışı üzerinde etkileri olduğunu ortaya koymaktadır. Bunlara ek olarak çalışanların söz konusu davranışları göstermelerindeki en önemli unsurlar arasında yöneticiye yönelik algıları yer almaktadır (Piccolo, vd., 2018). Yapılan meta analiz çalışmalarının sonuçları da çalışanların yöneticileri ile olan ilişkilerinin örgütsel vatandaşlık davranışları üzerinde etkili olduğunu göstermektedir (Spitzmuller, vd., 2008). Buradan hareketle aşağıdaki hipotezler öne sürülmektedir:

Yöneticinin $\left(\mathrm{H}_{1 \mathrm{a}}\right)$ ahlâki davranışlarına, $\left(\mathrm{H}_{1 b}\right)$ dürüstlüğüne ve $\left(\mathrm{H}_{1 c}\right)$ tutarlı olmasına ilişkin algılarının çalışanların bireye yönelik örgütsel vatandaşlık davranışları üzerinde pozitif yönlü etkisi vardır.

Yöneticinin $\left(\mathrm{H}_{2 \mathrm{a}}\right)$ ahlâki davranışlarına, $\left(\mathrm{H}_{2 b}\right)$ dürüstlüğüne ve $\left(\mathrm{H}_{2 c}\right)$ tutarlı olmasına ilişkin algılarının çalışanların örgüte yönelik örgütsel vatandaşlık davranışları üzerinde pozitif yönlü etkisi vardır.

Çalışma yaşamında bireysel ve ortak amaçlara ulaşılabilmesi bireylerin karşııklı güvenini içermektedir (Mayer, Davis ve Schoorman, 2006). Örgütlerde güvenin söz konusu olabilmesi ise yöneticilerin genel tutum ve davranışlarıyla yakından ilgilidir (Creed ve Miles, 1996). Çalışanlar, yöneticilerinin sözleri ve davranışlarının tutarlı olup olmadığını inceleyerek dürüstlüğüne ilişkin çıkarımlarda bulunmakta ve söz konusu bu nitelemeler de çalışanın yöneticisine olan güveni üzerinde etkili olmaktadır (Whitener, Brodt, Korsgaard ve Werner, 2006: 145-146). Güven temel olarak yöneticiyle olan ilişkiye bağlı olarak gelişmekte olup (Klaussner, 2012) tarafların dürüst olmaları güvenin temel öncüllerinden birisi olarak ortaya çıkmaktadır (Simons, 2002). Bu bağlamda aşağıdaki hipotezler öne sürülmektedir:

Yöneticinin $\left(\mathrm{H}_{3 a}\right)$ ahlâki davranışlarına, $\left(\mathrm{H}_{3 b}\right)$ dürüstlüğüne ve $\left(\mathrm{H}_{3 c}\right)$ tutarlı olmasına ilişkin algılarının çalışanların yöneticiye olan güvenleri üzerinde pozitif yönlü etkisi vardır.

Güven, insan yaşamındaki en temel gereksinimlerden birisi olarak karşımıza çıkmaktadır. Çalışma hayatında da ilişkilerin güven üzerinde kurulması çalışanların işlerine, örgüte, çalışma arkdaşlarına ve yöneticilerine ilişkin algı, tutum ve davranışları üzerinde etkileri söz konusu olacaktır (Örn., Dirks ve Ferrin, 2002; Wong, Ngo ve Wong, 2003; Colquitt, Scott ve Lepine, 2007; Simons, vd., 2007). Özellikle görev tanımları 
dışında gösterilecek rol ötesinde davranışların sergilenebilmesinde, çalışanların örgütsel vatandaşlık davranışları sergilemelerinde yöneticiye duyulan güven önemli bir yer tutmaktadır (Örn., Podsakoff, MacKenzie, Moorman ve Fetter, 1990; Wat ve Schaffer, 2005; Rubin, Bommer ve Bachrach, 2010). Bu çerçevede aşağıdaki hipotez öne sürülmektedir:

Çalışanların yöneticiye olan güvenlerinin $\left(\mathrm{H}_{4 a}\right)$ bireye yönelik ve $\left(\mathrm{H}_{4 b}\right)$ örgüte yönelik örgütsel vatandaşlık davranışları üzerinde pozitif yönlü etkisi vardır.

Yöneticinin çalışanlar tarafından dürüst olarak algılanmasının yöneticiye olan güvenlerini şekillendirdiği bilinmekte olup (Örn., Moorman, vd., 2013; Poon, 2013; Simons, Leroy, Collewaert ve Masschelein, 2015) yöneticiye duyulan güvenin ise çalışanların örgütsel vatandaşlık davranışı üzerinde etkili olduğu çeşitli çalışmalarda gösterilmiştir (Örn., Dirks ve Ferrin, 2002; Wat ve Schaffer, 2005; Colquitt vd., 2007). Buna göre çalışanın yöneticisinin dürüst olduğuna yönelik algısının oluşması, çalışanın yöneticisine güven duymasını sağlayacak, bu güven duygusu ise çalışanların örgütsel vatandaşlık davranışı sergilemeleri üzerinde etkili olacaktır. Buradan hareketle yöneticinin dürüstlüğünün çalışanların örgütsel vatandaşık davranışına etkisinde yöneticiye olan güvenin aracı etkisi olduğu yönünde aşağıdaki hipotezler öne sürülmektedir:

Yöneticinin $\left(\mathrm{H}_{5 a}\right)$ ahlâki davranışlarına, $\left(\mathrm{H}_{5 b}\right)$ dürüstlüğüne ve $\left(\mathrm{H}_{5 c}\right)$ tutarlı olmasına ilişkin algılarının çalışanların bireye yönelik örgütsel vatandaşlık davranışlarına etkisinde yöneticiye olan güvenin aracılık etkisi vardır.

Yöneticinin $\left(\mathrm{H}_{6 a}\right)$ ahlâki davranışlarına, $\left(\mathrm{H}_{6 b}\right)$ dürüstlüğüne ve $\left(\mathrm{H}_{6 c}\right)$ tutarlı olmasına ilişkin algılarının çalışanların örgüte yönelik örgütsel vatandaşlık davranışlarına etkisinde yöneticiye olan güvenin aracılık etkisi vardır.

Çalışma kapsamında geliştirilmiş olan araştırma modeli aşağıda görülmektedir (Bkz. Şekil 1).

Şekil 1. Araştırma Modeli

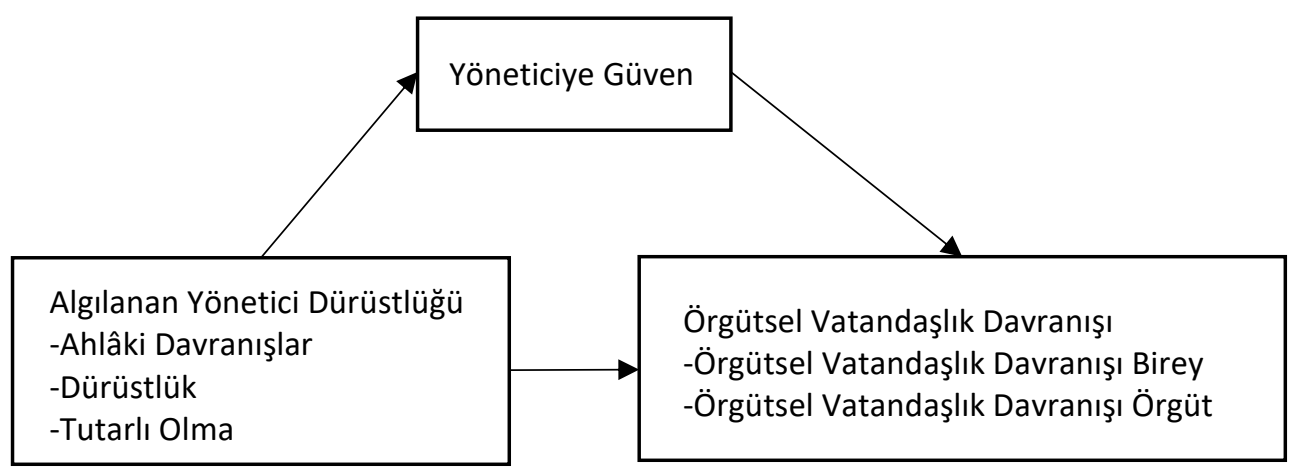

\section{Yöntem}

\section{1. Örneklem}

Araştırmada veri analizinde kullanılan veri kolayda örnekleme yöntemi dikkate alınarak Adana'da görevlerini sürdürmekte olan banka çalışanlarından anket ile elde edilmiştir. Veri toplamak amacıyla toplam olarak 450 anket dağıtılmış olmakla birlikte, 432 anket geri dönmüş ancak 19 anket uygun şekilde yanıtlanmamış olması nedeniyle çalışma dışında bırakılmış ve toplamda 413 veri ile analizler yapılmıştır. Bu çerçevede araştırmaya dâhil olan katılımcıların 214'ü kadınlardan oluşurken 199'u erkeklerden oluşmaktadır. Anketi yanıtlayanların yaş ortalamaları $39,77(S S=7,56)$ olarak elde edilmiş olup, çalışma süreleri ortalaması 15,28 (SS = 7,67) olarak belirlenmiştir. Katılımcıların eğitim durumları ise \%4,6'sı lise, \%79,6'sı önlisans ve lisans, \%15,7'si ise yüksek lisans olarak tespit edilmiştir (Bkz. Tablo1). 
Tablo 1. Örnekleme İlişkin Demografik Veriler

\begin{tabular}{llllll}
\hline Cinsiyet & $\mathrm{F}$ & $\%$ & Medeni Durum & $\mathrm{F}$ & $\%$ \\
Kadın & 214 & 51,8 & Evli & 308 & 74,6 \\
Erkek & 199 & 48,2 & Bekâr & 105 & 25,4 \\
Toplam & 413 & 100,0 & Toplam & 413 & 100,0 \\
\hline Yaş & $\mathrm{F}$ & $\%$ & Eğitim Durumu & $\mathrm{F}$ & $\%$ \\
$21-30$ & 51 & 12,3 & & & \\
$31-40$ & 174 & 42,1 & Lise & 19 & 4,6 \\
$41-50$ & 165 & 40,0 & Ön Lisans & 81 & 19,6 \\
$51-60$ & 16 & 3,9 & Lisans & 248 & 60,0 \\
61 ve üstü & 7 & 1,7 & Lisansüstü & 65 & 15,7 \\
Toplam & 413 & 100,0 & Toplam & 413 & 100,0 \\
\hline Toplam Çalışma Süresi & $\mathrm{F}$ & $\%$ & Mevcut İşyerinde Çalışma Süresi & $\mathrm{F}$ & $\%$ \\
$1-5$ yıl & 43 & 10,4 & $1-5$ yıl & 177 & 42,9 \\
$6-10$ yıl & 74 & 17,9 & $6-10$ yıl & 102 & 24,7 \\
$11-15$ yıl & 104 & 25,2 & $11-15$ yıl & 72 & 17,4 \\
$16-20$ yıl & 84 & 20,3 & $16-20$ yıl & 38 & 9,2 \\
21 yıl üzeri & 108 & 26,2 & 21 yıl üzeri & 24 & 5,8 \\
Toplam & 413 & 100,0 & Toplam & 413 & 100,0 \\
\hline
\end{tabular}

\subsection{Veri Toplama Araçları}

Çalışmada alde edilen veri anket yöntemi kullanılarak toplanmıştır. Söz konusu anketteki ifadelerin yanıtlanmasında 5'li Likert ölçeği dikkate alınmıştır. Ankette yönetici dürüstlüğü, yöneticiye güven ve örgütsel vatandaşık davranışlarını ölçmeye yönelik ifadelere ek olarak anketi yanıtlayanların cinsiyet, yaş, medeni durum, çalışma süreleri ve eğitim seviyelerine yönelik demografik ifadeler de yer almıştır.

Yönetici Dürüstlüğü Ölçeği. Çalışma kapsamında yönetici dürüstlüğünü ölçmek amacıyla Moorman vd. (2013) tarafından geliştirilmiş olan lider dürüstlüğü ölçeği dikkate alınmıştır. Söz konusu ölçek ahlâki değerler, dürüstlük ve tutarlı olma boyutlarından oluşmaktadır. Ahlâki değerler boyutunda altı ifade, dürüstlük boyutunda altı ifade ve tutarlı olma boyutunda ise dört ifade yer almaktadır. Söz konusu ölçeğin güvenirlik değerleri Moorman vd. (2013) tarafından yapılan araştırmada iki farklı çalışmada 0,86 ve 0,$94 ; 0,91$ ve 0,$95 ; 0,79$ ve 0,92 olarak tespit edilmiştir.

Yöneticiye Güven Ölçeği. Bu çalışmada yöneticiye güven değişkenini ölçmek için Simons vd. (2007) tarafından geliştirilmiş olan üç ifadeli ve tek boyuttan oluşan ölçüm aracı kullanışmıştır. Söz konusu çalışmada bu ölçeğin iç tutarlık katsayısı 0,85 olarak tespit edilmiştir.

Örgütsel Vatandaşlık Davranışı Ölçeği. Bu araştırma kapsamında örgütsel vatandaşlık davranışını ölçmek amacıyla Williams ve Anderson (1991) tarafından geliştirilmiş olan örgütsel vatandaşlık davranışı ölçeği dikkate alınmıştır. Bu ölçek bireye yönelik örgütsel vatandaşlık davranışı ve örgüte yönelik örgütsel vatandaşlık davranışı olmak üzere iki boyuttan ve on dört ifadeden oluşmaktadır. Söz konusu çalışmada ölçeğin iç tutarlık katsayıları sırasıyla 0,88 ve 0,75 olarak tespit edilmiştir.

\section{3. İşlem}

Araştırma kapsamında toplanan verilerin analizlerinin yapılmasında istatistik paket programlar kullanılmıştır. Çalışmada kullanılan ölçeklerin iç tutarlıııklarını ortaya koymak amacıyla Cronbach Alfa katsayısı ve bileşik güvenirlik katsayısı kullanılmıştır. Araştırmada ortaya konulan ölçüm modelinin yapısal geçerliğini belirlemek için doğrulayıcı faktör analizi yapılmış ve ayrışma ile birleşme geçerlikleri ortaya konulmuştur. Bunlara ek olarak araştırmada ele alınana değişkenler arasındaki ilişkiler Pearson korelasyon analizi yapılarak 
tespit edilmiştir. Çalışmada öne sürülen hipotezlerin test edilmesinde yapısal eşitlik modeli analizi ele alınmış ve böylece değişkenler arasında ortaya koyulması amaçlanılan doğrudan, dolaylı ve toplam etkiler tespit edilmiştir.

\section{Bulgular}

Çalışmada öncelikle ölçeklerin geçerliklerini tespit etmek amacıyla doğrulayıcı faktör analizi yapılmıştır. Bunun için en yüksek olabilirlik kestirim yöntemi (maximum likelihood) ele alınmıştır. Analiz sonucunda elde edilmiş olan katsayılar Şekil 2'de görülmektedir. Söz konusu bulgulara göre elde edilen faktör yükleri 0,723 ile 0,829 arasında değişen yüksek değerler almış olup, bu faktör yüklerinin tamamı istatistiksel olarak anlamlı bulunmuştur. Yapılan analiz sonucunda elde edilen model uyum iyiliği değerleri doğrulayıcı faktör analizi modelinin iyi uyum sağladığına işaret etmektedir $\left(\chi^{2}=587,000 ; s d=480 ; \chi^{2} / s d=1,223 ; p<0,01\right.$; $\mathrm{CFI}=0,986 ; \mathrm{TLI}=0,985 ; \mathrm{IFI}=0,986 ; \mathrm{RMSEA}=0,023 ; \mathrm{SRMR}=0,030)$. Buna göre karşılaştırmalı uyum indeksi (CFI) 0,986, Tucker Lewis indeksi (TLI) 0,985 ve artırmalı uyum indeksi (IFI) 0,986 olarak tespit edilmiş ve bu değerler modelin çok iyi uyumunu göstermektedir. Ayrıca yaklaşık hataların ortalama karekökü (RMSEA) 0,023 ve standardize edilmiş kalıntıların karekökü (SRMR) 0,030 olarak elde edilmiş olan değerleri ile yine çok iyi uyumu göstermektedir.

Şekil 2. Doğrulayıcı Faktör Analizi

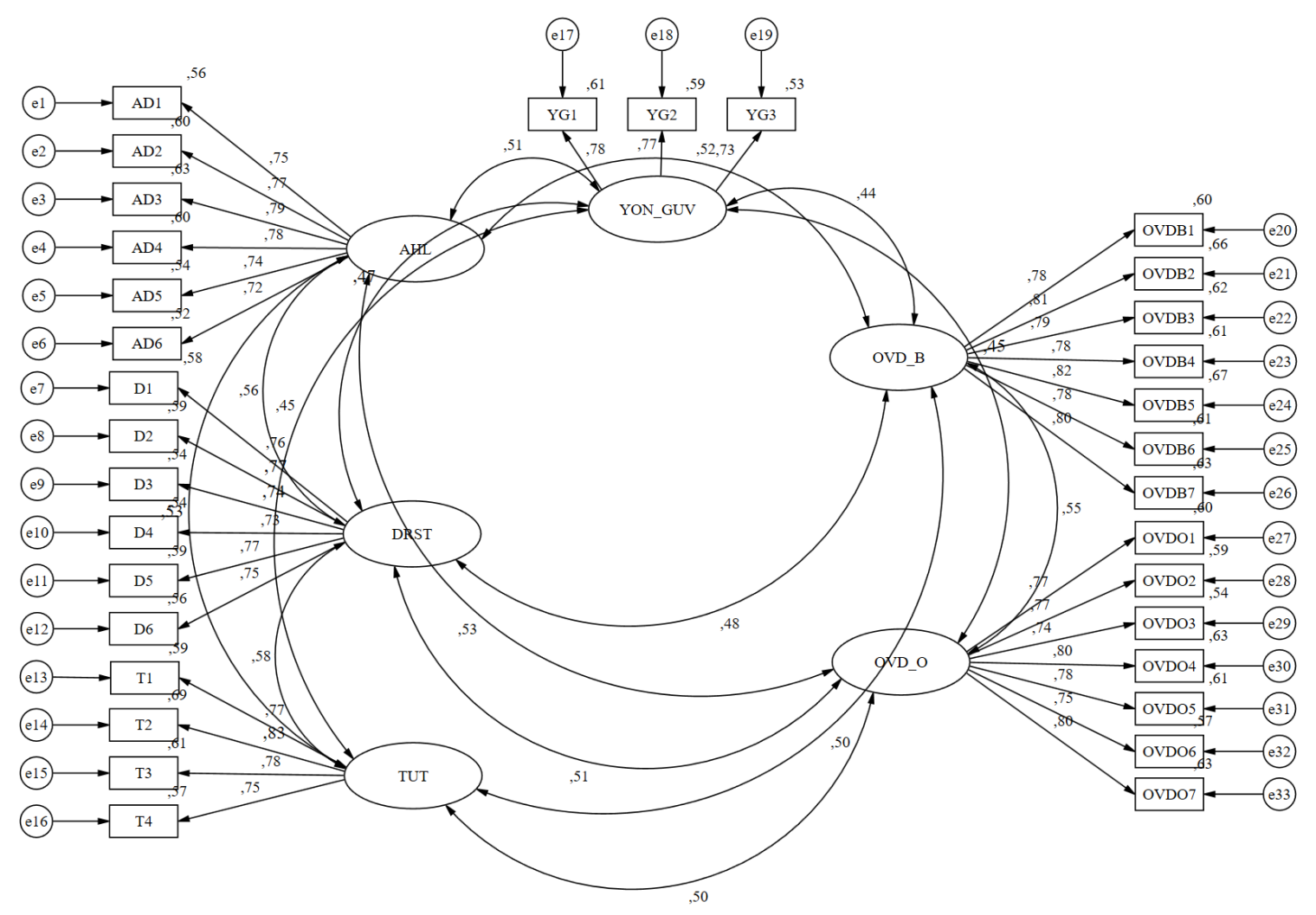

Yapılan doğrulayıcı faktör analizi ile ayrışma ve birleşme geçerliğinin ortaya koyulması amacıyla ortalama açıklanan varyans (AVE), ortalama paylaşılan varyans (ASV), en yüksek paylaşılan varyans (MSV), bileşik güvenirlik katsayısı (CR), faktör yükleri ve değişkenler arasındaki ilişkiler değerlendirilmiştir. Buna göre birleşme geçerliğinin sağlanabilmesi için doğrulayıcı faktör analizi sonucunda elde edilen faktör yüklerinin 0,50 veya tercihen $0,70^{\prime}$ in üzerinde, ortalama açıklanan varyans (AVE) değerlerinin 0,50 'den ve yapı geçerliği (CR) katsayılarının ise 0,70'den büyük olması şartlarının sağlanması gerekmektedir (Hair, Black, Babin ve Anderson, 2014: 605). Ayrışma geçerliğinin sağlanabilmesi için ise ortalama ve en yüksek paylaşılan varyans (ASV, MSV) değerlerinin ortalama açıklanan varyans (AVE) değerlerinden küçük olması gerekirken, AVE 
karekök değerlerinin değişkenler arasındaki korelasyonlar değerlerinden büyük olması gerekmektedir (Hair vd., 2014: 631).

Bu çerçevede doğrulayıcı faktör analizi sonucunda faktör yüklerinin tamamının 0,70 'in üzerinde olduğu tespit edilmiştir. Ayrıca Tablo 2'de görüldüğü üzre AVE değerlerinin tamamı 0,50 ve CR değerleri ise 0,70 'den büyük değerler almış olması çalışmada birleşme geçerliğinin sağlandığını ortaya koymaktadır. Bunlara ek olarak ayrışma geçerliğinin sağlanması bağlamında ASV ve MSV değerlerinin tamamının AVE değerlerinden küçük olduğu belirlenmiş olmakla birlikte AVE karekök değerlerinin de değişkenler arasındaki ilişkilerden büyük olduğu tespit edilmiştir (Bkz. Tablo 2). Bu bulgular doğrultusunda çalışmada ayrışma ve birleşme geçerliği ile birlikte yapı geçerliğinin de sağlandığının söylenmesi mümkündür.

Tablo 2. Değişkenlere Ait Ortalama, Standart Sapma, Cronbach Alfa, CR, AVE, MSV, ASV Değerleri ve Değişkenler Arasındaki Korelasyon Değerleri $(n=413)$

\begin{tabular}{|c|c|c|c|c|c|c|c|c|c|c|c|c|}
\hline Değişkenler & Ort. & SS & $C R$ & AVE & MSV & ASV & 1 & 2 & 3 & 4 & 5 & 6 \\
\hline $\begin{array}{l}\text { 1.Ahlaki } \\
\text { Davranış }\end{array}$ & 4,61 & ,51 & 89 & ,58 & ,31 & , 28 &, $89^{\alpha}$ & & & & & \\
\hline 2.Dürüstlük & 4,55 & ,53 & ,89 & ,57 & 34, & 27, &, $56^{* * *}$ &, $89^{\alpha}$ & & & & \\
\hline $\begin{array}{l}\text { 3.Tutarlı } \\
\text { Olma }\end{array}$ & 4,39 & ,64 & ,86 & ,62 & ,34 & ,27 &, $53^{* * *}$ &, $58^{* * *}$ &, $86^{\alpha}$ & & & \\
\hline $\begin{array}{l}\text { 4.Yöneticiye } \\
\text { Güven } \\
\text { 5.Örgütsel }\end{array}$ & 4,48 & ,58 & ,81 &, 58 & ,26 & ,22 &, $51^{* * *}$ &, $47^{* * *}$ &, $45^{* * *}$ &, $80^{\alpha}$ & & \\
\hline $\begin{array}{l}\text { Vatandaşlık } \\
\text { Davranışı- } \\
\text { Birey } \\
\text { 6.Örgütsel }\end{array}$ & 4,51 & ,59 & ,92 & ,63 & ,30 & ,25 &, $52^{* * *}$ &, $48^{* * *}$ &, $50^{* * *}$ &, $44^{* * *}$ &, $92^{\alpha}$ & \\
\hline $\begin{array}{l}\text { Vatandaşlık } \\
\text { Davranışı- } \\
\text { Örgüt }\end{array}$ & 4,49 &, 57 & ,91 & ,60 & ,30 & ,26 &, $53^{* * *}$ &, $51^{* * *}$ &, $50^{* * *}$ &, $45^{* * *}$ &, $55^{* * *}$ & $91^{\alpha}$ \\
\hline
\end{tabular}

Araştırma kapsamında kullanılan ölçeklerin güvenirliklerini belirlemek amacıyla Cronbach Alfa katsayısı ile bileşik güvenirlik katsayıları dikkate alınmıştır (Bkz. Tablo 2). Buna göre yönetici dürüstlüğü ölçeğinin ahlâki değerler boyutu için Cronbach Alfa katsayısı 0,89; dürüstülük boyutu için 0,89; tutarlı olma boyutu için ise 0,86 olarak elde edilmiştir. Ayrıca yöneticiye güven değişkeni için Alfa katsayısı 0,80; örgütsel vatandaşlık alt boyutları için; bireye yönelik davranış için 0,92 ve örgüte yönelik davranışlar için ise 0,91 olarak tespit edilmiştir. Bunların yanında ahlâki değerler alt boyutunun bileşik güvenirlik katsayısı 0,89; dürüstlük boyutunun 0,89 ; tutarlı olma boyutunun 0,86 olarak belirlenmiştir. Benzer şekilde yöneticiye güven değişkeni için bileşik güvenirlik katsayısı ise 0,81 olarak bulunmuştur. Son olarak ise örgütsel vatandaşlık davranışı için bileşik güvenirlik katsayısı; bireye yönelik örgütsel vatandaşlık davranışı için 0,92 ve örgüte yönelik örgütsel vatandaşıı davranışı için ise 0,91 olarak elde edilmiştir. Ortaya konulmuş olan Cronbach Alfa katsayıları ve bileşik güvenirlik katsayılarının tamamının 0,70'in üzerinde olması (Hair vd., 2014) ölçeklerin güvenirliğinin sağlandığına işaret etmektedir.

Çalışma kapsamında kullanıımış olan değişkenler arasındaki korelasyon katsayıları Tablo 2'de görülmektedir. Buna göre ahlâki değerler ile dürüstlük $(r=0,56 ; p<0,01)$, tutarlı olma $(r=0,53 ; p<0,01)$, yöneticiye güven $(r=0,51 ; p<0,01)$, örgütsel vatandaşlık davranışı-birey $(r=0,52 ; p<0,01)$ ve örgütsel vatandaşlık davranışı-örgüt $(r=0,53 ; p<0,01)$ arasındaki ilişkilerin anlamlı olduğu tespit edilmiştir. Ayrıca dürüstlük ile tutarlı olma $(r=0,58 ; p<0,01)$, yöneticiye güven $(r=0,47 ; p<0,01)$, örgütsel vatandaşık davranışı-birey $(r=0,48 ; p<0,01)$ ve örgütsel vatandaşlık davranışı-örgüt $(r=0,51 ; p<0,01)$ ilişkileri de istatistiksel olarak anlamlı ve pozitif yönlü olarak elde edilmiştir. Benzer olarak tutarlı olma ile yöneticiye 
güven ( $r=0,45 ; p<0,01)$, örgütsel vatandaşlık davranışı-birey $(r=0,50 ; p<0,01)$ ve örgütsel vatandaşlık davranışı-örgüt $(r=0,50 ; p<0,01)$ arasındaki korelasyon katsayıları pozitif yönlü ve anlamlı olarak belirlenmiştir. Bunlara ek olarak yöneticiye güven ile örgütsel vatandaşlık davranışı-birey $(r=0,44 ; p<0,01)$ ve örgütsel vatandaşlık davranışı-örgüt $(r=0,45 ; p<0,01)$ ilişkileri de anlamlı olarak elde edilmiştir. Son olarak ise örgütsel vatandaşlık davranışı-birey ve örgütsel vatandaşlık davranışı-örgüt $(r=0,55 ; p<0,01)$ ilişkisi de pozitif yönlü ve istatistiksel olarak anlamlı bulunmuştur.

Araştırmada ele alınan model ve değişkenlere yönelik güvenirlik ve geçerlik analizleri ardından söz konusu değişkeler arasındaki doğrudan, dolaylı ve toplam ilişkileri tespit etmek amacıyla yapısal eşitlik modeli ile analizler yapılmıştır. Toplam etkilerin, doğrudan ve dolaylı etkilerin toplanmasıyla elde edilmesi söz konusu olmakla birlikte analizlerin net olarak anlaşılır bir biçimde ortaya konulması amacıyla ilk model test edilmiştir. Analiz en yüksek olabilirlik kestirim yöntemi (maximum likelihood) ile yapılmış olup, modeldeki katsayıların tamamı eş zamanlı olarak analiz edilmiştir. Çalışmada ilk olarak toplam etkileri incelemeye yönelik model test edilmiştir. Analiz sonucunda model uyum iyiliği değerleri çok iyi uyuma işaret etmektedir $\left(\chi^{2}=505,737\right.$; sd = 396; $\left.\chi^{2} / \mathrm{sd}=1,277 ; p<0,01 ; \mathrm{CFI}=0,985 ; \mathrm{TLI}=0,983 ; \mathrm{IFI}=0,985 ; \mathrm{RMSEA}=0,026 ; \mathrm{SRMR}=0,045\right)$. Buna göre karşılaştırmalı uyum indeksi (CFI) 0,985, Tucker Lewis indeksi (TLI) 0,983 ve artırmalı uyum indeksi (IFI) 0,985 olarak tespit edilmiş ve bu değerler modelin çok iyi uyumunu göstermektedir. Ayrıca yaklaşık hataların ortalama karekökü (RMSEA) 0,026 ve standardize edilmiş kalıntıların karekökü (SRMR) 0,045 olarak elde edilmiş olan değerleri ile yine çok iyi uyumu göstermektedir.

Tablo 3’te görüldüğü üzere yönetici dürüstlüğünün örgütsel vatandaşlık davranışına etkisi olduğunu ileri süren hipotezlerin desteklendiği tespit edilmiştir. Buna göre yönetici dürüstlüğünün alt boyutlarından birisi olan ahlâki davranışların bireye yönelik örgütsel vatandaşlık davranışları üzerinde $(\beta=0,29)$ ve örgüte yönelik örgütsel vatandaşlık davranışları üzerinde $(\beta=0,29)$ pozitif yönlü etkileri bulunmaktadır. Benzer olarak yönetici dürüstlüğünün diğer bir alt boyutu dürüstlük faktörünün bireye yönelik örgütsel vatandaşlık davranışları üzerinde $(\beta=0,18)$ ve örgüte yönelik örgütsel vatandaşlık davranışları üzerinde $(\beta=0,22)$ pozitif yönlü etkileri olduğu görülmektedir. Ayrıca tutarlı olma alt boyutunun bireye yönelik örgütsel vatandaşlık davranışları üzerinde $(\beta=0,25)$ ve örgüte yönelik örgütsel vatandaşlık davranışları üzerinde $(\beta=0,22)$ pozitif yönlü etkileri bulunduğu tespit edilmiştir. Elde edilen katsayılar, standart hata değerleri, \%95 güven aralığı değerleri ile önem düzeyleri de Tablo 3'te görülmektedir.

Tablo 3. Modeldeki Toplam Etkiler

\begin{tabular}{lllll}
\hline & $\begin{array}{l}\text { Örgütsel } \\
\text { Vatandaşlık } \\
\text { Davranışı-Birey }\end{array}$ & $\begin{array}{l}\text { Sapma Düzeltmesi } \\
\text { Yapılmış \%95 Güven } \\
\text { Aralığı }\end{array}$ & $\begin{array}{l}\text { Örgütsel } \\
\text { Vatandaşlık } \\
\text { Davranışı̈Örgüt }\end{array}$ & $\begin{array}{l}\text { Sapma Düzeltmesi } \\
\text { Yapılmış \%95 Güven } \\
\text { Aralığı }\end{array}$ \\
\hline $\begin{array}{l}\text { Ahlâki } \\
\text { Davranış }\end{array}$ &, $290^{* *}(, 061)$ &, $167-, 404$ &, $291^{* *}(, 063)$ &, $163-, 412$ \\
$\begin{array}{l}\text { Dürüstlük } \\
\text { Tutarlı }\end{array}$ &, $177^{* *}(, 065)$ &, $046-, 304$ &, $222^{* *}(, 067)$ &, $084-, 352$ \\
Olma &, $253^{* *}(, 065)$ &, $122-, 377$ &, $224^{* *}(, 065)$ &, $099-, 349$ \\
\hline
\end{tabular}

Not.- Parantez içindeki değerler standart hatalardır, ${ }^{*} p<, 05,{ }^{* *} p<, 01,{ }^{* * *} p<, 001$

Çalışma çerçevesinde doğrudan ve dolaylı etkileri ortaya koymak amacıyla aracı değişken modele dâhil ederek ikinci bir yapısal eşitlik modeli test edilmiştir. Analiz yapılırken yine en yüksek olabilirlik kestirim yöntemi (maximum likelihood) dikkate alınmıştır. Yapılan analiz sonucunda elde edilmiş olan dolaylı etkiler ve yol katsayıları Şekil 3'te yer almaktadır. Analiz bulgularına göre model uyum iyiliği değerleri çok iyi uyuma işaret etmektedir $\left(\chi^{2}=609,413 ; s d=481 ; \chi^{2} / s d=1,267 ; p<0,01 ; C F I=0,983 ; \mathrm{TLI}=0,982 ; \mathrm{IFI}=0,984\right.$; RMSEA $=0,025 ;$ SRMR $=0,041$ ). Buna göre karşılaştırmalı uyum indeksi (CFI) 0,983, Tucker Lewis indeksi (TLI) 0,982 ve artırmalı uyum indeksi (IFI) 0,984 olarak tespit edilmiş ve bu değerler modelin çok iyi uyumunu göstermektedir. Ayrıca yaklaşık hataların ortalama karekökü (RMSEA) 0,025 ve standardize edilmiş kalıntıların karekökü (SRMR) 0,041 olarak elde edilmiş olan değerleri ile yine çok iyi uyumu göstermektedir. 
Şekil 3. Yapısal Modelde Doğrudan ve Dolaylı Etkiler ile Standartlaştııılmış Yol Katsayıları

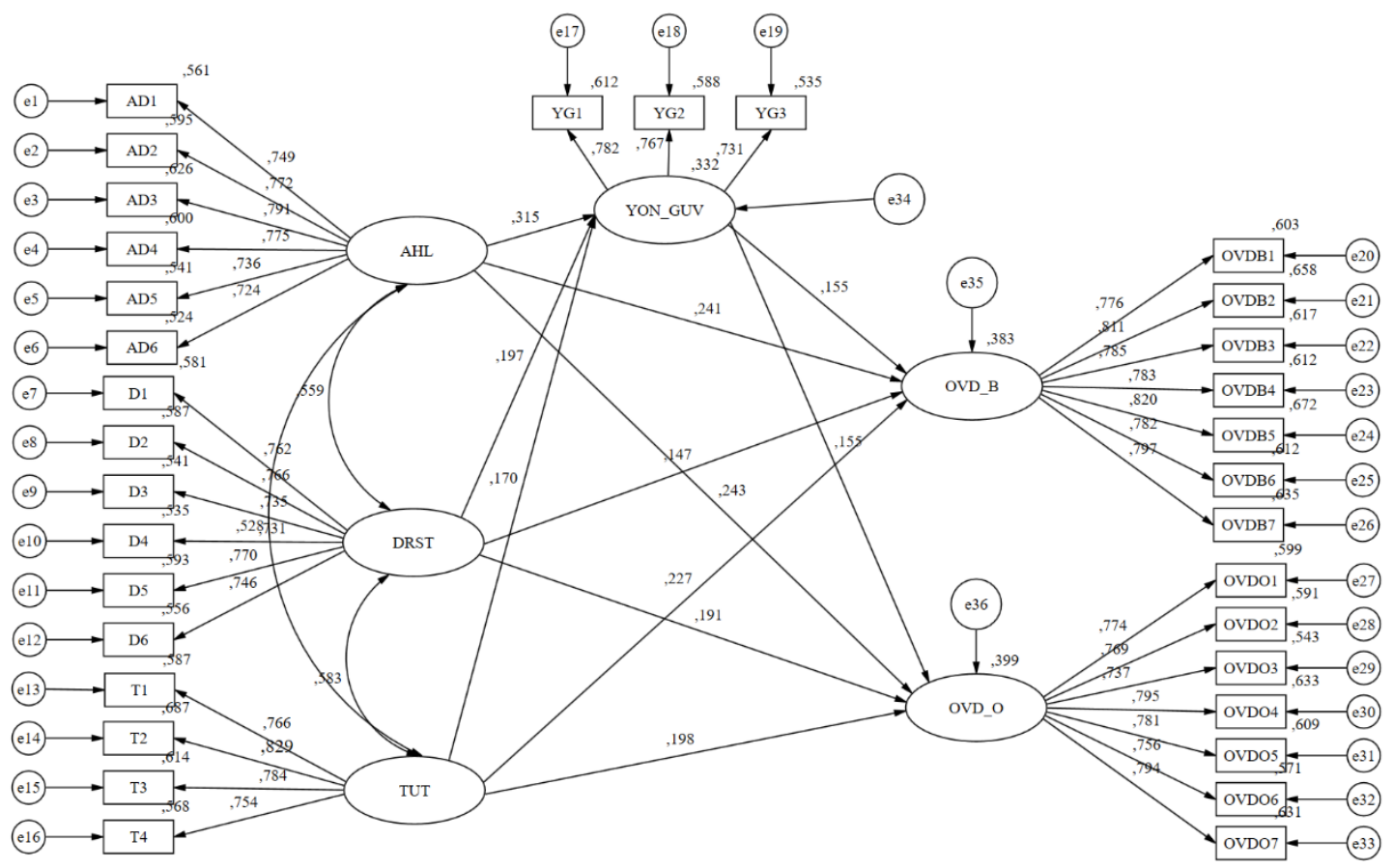

Tablo 4. Modeldeki Yol Katsayıları ve Dolaylı Etkiler

\begin{tabular}{|c|c|c|c|c|c|}
\hline & & & & \multicolumn{2}{|c|}{ Dolaylı Etkiler } \\
\hline & \multicolumn{2}{|c|}{ Yol Katsayıları } & & \multirow[b]{4}{*}{ Ölçüm Değeri } & \multirow{4}{*}{$\begin{array}{l}\text { Sapma } \\
\text { Düzeltmesi } \\
\text { Yapılmış \%95 } \\
\text { Güven Aralığ }\end{array}$} \\
\hline & Örgütsel & Örgütsel & Yöneticiye & & \\
\hline & Vatandaşlık & Vatandaşlık & Güven & & \\
\hline & Davranışı-Birey & Davranışı-Örgüt & & & \\
\hline Ahlâki Davranış &, $243^{* * *}(, 065)$ &, $243^{* * *}(, 067)$ &, $315^{* * *}(, 068)$ & & \\
\hline Dürüstlük &, $147^{*}(, 067)$ &, $191^{* * *}(, 069)$ &, $197^{* * *}(, 073)$ & & \\
\hline Tutarlı Olma &, $227^{* * *}(, 066)$ &, $198^{* * *}(, 065)$ &, $170^{*}(, 072)$ & & \\
\hline Yöneticiye Güven &, $155^{*}(, 066)$ &, $155^{*}(, 065)$ & & & \\
\hline$A D \rightarrow Y G \rightarrow$ OVD-B & & & &, $049^{*}(, 023)$ & 102, - 010 \\
\hline$A D \rightarrow Y G \rightarrow$ OVD-O & & & &, $049^{*}(, 024)$ & , 010 - 106 \\
\hline $\mathrm{DRS} \rightarrow \mathrm{YG} \rightarrow$ OVD-B & & & &, $031^{*}(, 018)$ & ,005-,077 \\
\hline $\mathrm{DRS} \rightarrow \mathrm{YG} \rightarrow$ OVD-O & & & &, $030^{*}(, 018)$ & ,005-, 079 \\
\hline TUT $\rightarrow$ YG $\rightarrow$ OVD-B & & & &, $026^{*}(, 016)$ & ,003-, 068 \\
\hline TUT $\rightarrow$ YG $\rightarrow$ OVD-O & & & &, $026^{*}(, 017)$ & ,003-, 071 \\
\hline
\end{tabular}

Not.- Hayes, Preacher ve Myers (2011)'den uyarlanmıştır. Parantez içindeki değerler standart hatalardır, ${ }^{*} p<, 05,{ }^{* *} p<, 01$, ${ }^{* * *} p<, 001$

Bu bulgulara göre yönetici dürüstlüğünün (ahlâki değerler $(\beta=0,32)$, dürüstlük $(\beta=0,20)$, tutarlı olma $(\beta=0,17))$ yöneticiye güven üzerinde pozitif yönlü etkisi olduğu görülmektedir. Ayrıca yöneticiye güven değişkeninin çalışanların örgütsel vatandaşlık davranışı (bireye yönelik örgütsel vatandaşlık davranışı ( $\beta=$ $0,16)$, örgüte yönelik örgütsel vatandaşlık davranışı $(\beta=0,16))$ üzerinde pozitif yönlü etkileri olduğu ortaya konulmuştur. Böylece hipotezlerin de desteklendiği belirlenmiştir. Bunlara ilaveten dolaylı etkilere yönelik olarak ahlâki davranışın bireye yönelik örgütsel vatandaşık davranışına $(\beta=0,24)$ ve örgüte yönelik örgütsel 
vatandaşılk davranışına $(\beta=0,24)$ etkisinde yöneticiye güvenin aracılık etkisinin olduğu görülmektedir (Bkz. Tablo 4). Ayrıca yine yönetici dürüstlüğünün alt boyutu olan dürüstlüğün bireye yönelik örgütsel vatandaşılk davranışına $(\beta=0,15)$ ve örgüte yönelik örgütsel vatandaşlık davranışına $(\beta=0,19)$ etkisinde yöneticiye güvenin aracılık etkisinin olduğu belirlenmiştir (Bkz. Tablo 4). Son olarak ise tutarlı olma boyutunun bireye yönelik örgütsel vatandaşlık davranışına $(\beta=0,23)$ ve örgüte yönelik örgütsel vatandaşlık davranışına $(\beta=$ 0,20 ) etkileri olduğu tespit edilmiştir (Bkz. Tablo 4). Bu doğrultuda söz konusu etkilere yönelik ileri sürülmüş olan hipotezlerin desteklendiği görülmektedir.

Şekil 4. Modele İlişkin Katsayılar, Standart Hatalar ve Açıklanan Varyans Değerleri

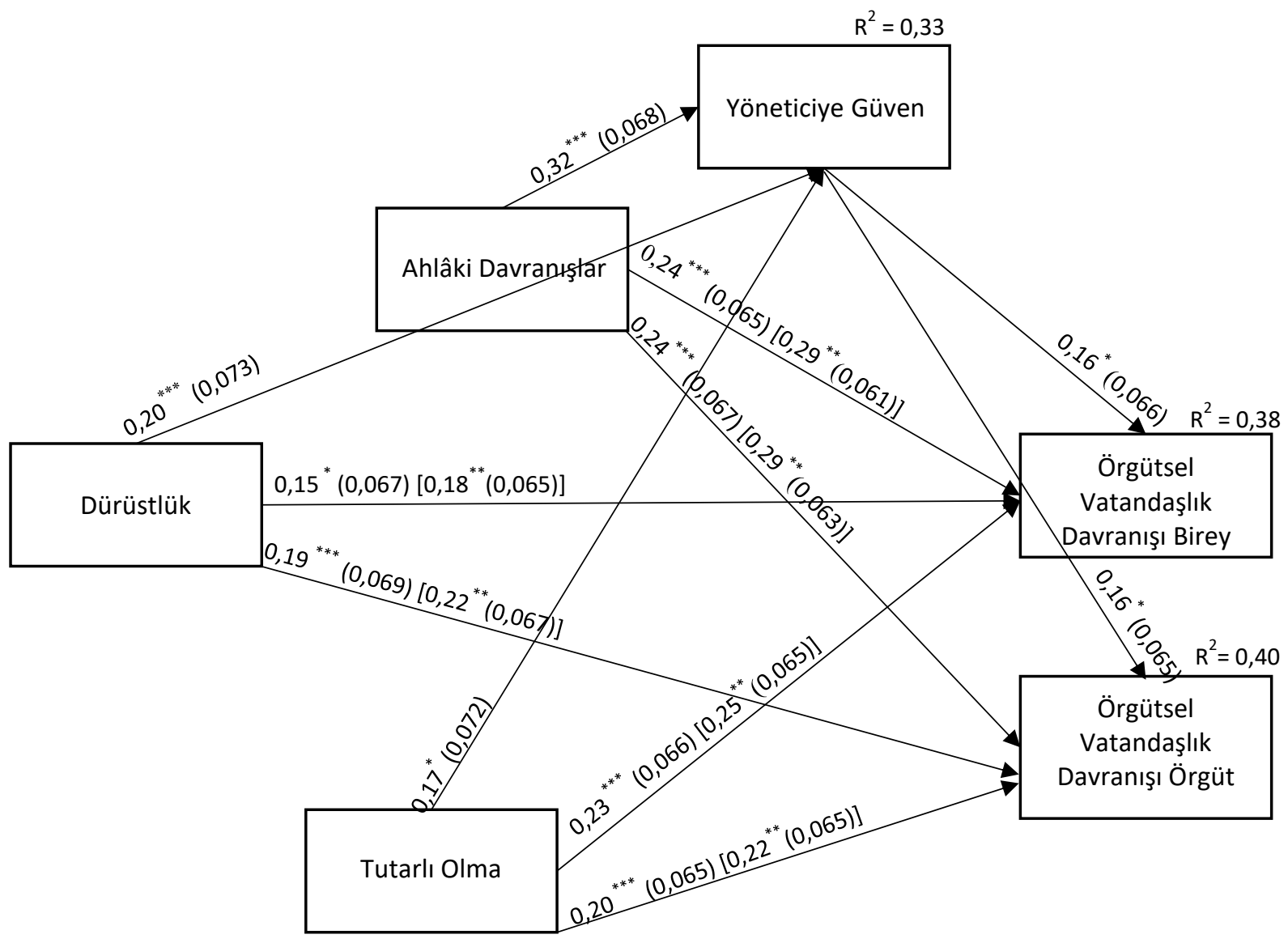

Çalışma kapsamında aracılık etkilerine ilişkin hipotezleri test etmek amacıyla Preacher ve Hayes (2004) tarafından geliştirilmiş olan yöntem dikkate alınmıştır (Hayes, 2018). Bu yaklaşımda değişkenler arasındaki dolaylı etkiler bootstrap yöntemi (Bollen ve Stein, 1990) kullanılarak tespit edilmektedir. Alan yazında aracılık etkilerini ortaya koymak amacıyla farklı teknikler kullanılmaktadır (MacKinnon, Lockwood, Hoffman, West ve Sheets, 2002). Söz konusu bu yaklaşımlardan en çok bilinen ve ele alınan yöntem ise Baron ve Kenny'nin (1986) yazına kazandırmış olduğu nedensel aşamalar tekniğidir (Hayes, 2009: 410). Ancak söz konusu yöntemin istatistik açıdan gücünün zayıf olması (MacKinnon vd., 2002; Fritz ve MacKinnon, 2007) ve aracılık etkisini sayısallaştıramıyor oluşu benzeri farklı nedenlerle eleştiri alan bir teknik olup (Hayes, 2009) aracılık etkilerini belirlemede kullanılması tavsiye edilmemektedir (MacKinnon, vd., 2002; Hayes, 2018). Bu bilgiler doğrultusunda bu araştırma kapsamında dolaylı etkileri belirlemede daha etkili olan ve tip I hatayı en aza indirebilen bootstrap yöntemi (Hayes ve Scharkow, 2013) kullanılmıştır. Bootstrap için 5000 yeniden örnekleme ve sapma düzeltmesi yapılmış \%95 güven aralığı dikkate alınmıştır. Güven aralıklarının sıfır içermemesi durumunda aracılık etkisinin anlamlı olduğu söylenebilmektedir (Preacher ve Hayes, 2008). 
Gerçekleştirilen analiz sonucunda ortaya konulan bulgular Tablo 4'te görülmektedir. Söz konusu bu bulgulara göre ahlâki davranışın bireye yönelik örgütsel vatandaşlık davranışına $(\beta=0,049 *(0,023)$, Bca $\% 95 G A=[0,010-0,102])$ ve örgüte yönelik örgütsel vatandaşlık davranışına $(\beta=0,049 *(0,024)$, Bca \%95GA $=[0,010-0,106])$ etkisinde yöneticiye güvenin aracılık etkisi olduğuna yönelik hipotezlerin desteklendiği görülmektedir. Benzer olarak dürüstlüğün bireye yönelik örgütsel vatandaşlık davranışına $(\beta=0,031 *(0,018)$, Bca \%95GA $=[0,005-0,077])$ ve örgüte yönelik örgütsel vatandaşlık davranışına $(\beta=0,030 *(0,018), B c a$ $\% 95 G A=[0,005-0,079])$ etkisinde yöneticiye güvenin aracilık etkisi olduğuna ilişkin hipotezlerin desteklendiği ortaya konulmuştur. Ayrıca yönetici dürüstlüğü değişkeninin alt boyutlarından olan tutarlı olma boyutunun bireye yönelik örgütsel vatandaşlık davranışına $\left(\beta=0,026^{*}(0,016), B c a \% 95 G A=[0,003-0,068]\right)$, ve örgüte yönelik örgütsel vatandaşık davranışına $\left(\beta=0,026^{*}(0,017), B c a \% 95 G A=[0,003-0,071]\right)$ etkisinde de yöneticiye güvenin aracılık etkisi olduğuna dair hipotezlerin desteklendiği görülmektedir (Bkz. Şekil 4). Bu bulgulara göre algılanan yönetici dürüstlügünün örgütsel vatandaşlık davranışı üzerindeki etkisinin, yöneticiye güvenin modele dâhil edilmesiyle söz konusu etkilerin önemsiz olmadığı ancak etkilerin azalarak önem düzeylerinin ise $p<0,05$ düzeyine geldiği diğer bir deyişle aracılık etkisinin bulunduğu görülmektedir.

\section{Sonuç ve Tartışma}

Bu çalışmada yöneticiye ilişkin dürüstlük algısının alt boyutları olan ahlâki davranışlar, dürüstlük ve tutarlı olmanın yöneticiye olan güven ile örgütsel vatandaşlık davranışının alt boyutları olan bireye yönelik örgütsel vatandaşlık davranışı ve örgüte yönelik örgütsel vatandaşlık davranışı üzerindeki doğrudan ve dolaylı etkilerinin ortaya koyulması amaçlanmaktadır. Bu doğrultuda banka çalışanlarından oluşan örneklemden elde edilmiş olan verinin analizleri sonucunda söz konusu doğrudan ve dolaylı etkiler ile bu etkilerin anlamlı olup olmadıkları ele alınmıştır.

Çalışmada ortaya konulmuş olan bulgulara göre yönetici dürüstlüğünün çalışanların yöneticiye olan güven düzeylerine pozitif yönlü etkileri olduğu tespit edilmiştir. Buna göre çalışanların yöneticinin dürüstlüğüne yönelik olumlu algıları yöneticiye duydukları güveni artırmaktadır. Söz konusu bu bulgular alan yazında daha önce ele alınmış çalışmaların sonuçları ile desteklenmektedir (Örn., Kannan-Narasimhan ve Lawrence, 2012; Moorman, vd., 2013; Poon, 2013; Simons vd., 2015; Boğan ve Dedeoğlu, 2016).

Çalışmada elde edilen bir diğer sonuç ise yöneticinin dürüst olduğuna yönelik çalışanların algılarının, örgüte yönelik ve bireye yönelik örgütsel vatandaşlık davranışları üzerinde pozitif etkileri olmasıdır. Buna göre yöneticilerinin dürüstlüğüne kanaat getiren çalışanların örgütsel vatandaşlık davranışları da artmaktadır. Yapılan çalışmalarda bu sonuçları destekler nitelikte bulgular ortaya koymaktadır (Örn., Kannan-Narasimhan ve Lawrence, 2012; Zhang, Bai, Caza ve Wang, 2014; Simons, vd., 2015).

Araştırma sonucunda gösterilmiş olan diğer bir bulgu ise yöneticiye olan güvenin çalışanların hem bireye hem de örgüte yönelik örgütsel vatandaşlık davranışları üzerindeki pozitif yönlü etkilerinin bulunmasıdır. Bu sonuca göre çalışanları ile yöneticiler arasında kurulan güvene dayalı ilişkinin söz konusu olması, çalışanların örgütsel vatandaşlık davranışlarını artırmaktadır. Alan yazında söz konusu ilişkiye yönelik yapılmış olan araştırmalar da bu sonuçla örtüşmektedir (Örn., Podsakoff, vd., 1990; Deluga, 1995; Dirks ve Ferrin, 2002; Wong, vd., 2003; Wat ve Schaffer, 2005; Colquitt, vd., 2007; Rubin, vd., 2010).

Araştırma kapsamında gerçekleştirilen analiz sonuçlarına göre, yöneticinin dürüstlüğünün yöneticiye olan güven ile çalışanların örgütsel vatandaşlık davranışları üzerindeki pozitif yönlü etkisi ve yöneticiye duyulan güvenin örgütsel vatandaşlık davranışlarına olan pozitif yönlü etkilerinden hareketle, yöneticinin dürüst olarak algılanmasının çalışanların örgütsel vatandaşılı davranışları üzerindeki etkisinde yöneticiye olan güvenin kısmi aracılık etkisi olduğu gösterilmiştir. Buna göre çalışanların yöneticilerinin doğruluğuna ilişkin olumlu algılarının yüksek olması, söz konusu yöneticiye olan güven duygularını artırmakla birlikte bu yüksek güven düzeyi de çalışanların hem örgüte hem de bireye yönelik olan örgütsel vatandaşlık davranışlarını da artırmaktadır. Ancak alan yazında bu dolaylı ilişkiyi daha önce ele almış olan bir araştırma bulgusuna rastlanılması söz konusu olmamıştır.

Araştırma sonucunda ortaya konulmuş olan bu bulgular bağlamında yönetici ile olan ilişkilerde dürüstlük algısı çalışanların davranışlarını etkileyen unsurlardan birisi olarak karşımıza çıkmaktadır. Buna göre 
çalışanların olumlu ve istenilen tutum ve davranışlar sergilemelerini bekleyen yöneticlerin özellikle çalışanlar nazarındaki imgelerinin ne yönde şekillendiğine özen göstermeleri gerekmektedir. Benzer olarak çalışma ortamında karşılıklı güvenin tesis edilmesi özellikle de çalışanların yöneticiye olan güven düzeylerinin yüksek olmasının sağlanması, çalışanların olumlu algı, tutum ve davranışlarının pekiştirilmesine katkısı olacak önemli bir faktördür.

Her çalışmada olduğu üzere bu çalışmada da çeşitli kısıtlar bulunmaktadır. Söz konusu kısıtlardan ilki araştırmanın tek bir örneklemde gerçekleştirilmiş olmasıdır. Bu durumda sonuçların genellenebilir olmasından söz edilmesi mümkün olamamaktadır. İleride konuya yönelik yapılacak çalışmalarda farklı örneklemler seçilerek araştırmanın yapılması önem taşımaktadır. Çalışma kapsamında ortaya çıkan bir diğer kısıt ise araştırmanın kesitsel olmasıdır. Gelecekte yürütülecek araştırmalarda kesitsel çalışmalara ek olarak boylamsal araştırma kurgularını yapılması söz konusu ilişkilerin açıklanmasına katkı sağlayabilecektir. Çalışmanın başka bir kısıtı da araştırma modeli çerçevesinde yöneticiye ilişkin dürüstlük algısı ve yöneticiye güvenin yalnızca örgütsel vatandaşlık davranışı üzerindeki etkilerinin ele alınmış olmasıdır. İlerde yapılacak çalışmalarda çalışanların farklı davranışları ve tutumları da modele dâhil edilerek söz konusu etkilerin ortaya koyulması yarar sağlayabilecektir.

\section{Son Notlar}

* Bu çalışma, 28-29-30 Kasım 2018 tarihlerinde düzenlenen "IV. International Conference on Applied Economics and Finance \& Extended with Social Sciences (ICOAEF'18)" kongresinde sözlü olarak sunulmuş ve öz kısmı Bildiri Özetleri Kitabında yayınlanmıştır.

\section{Kaynaklar}

Arslantaş, C. C. (2008). Yöneticiye duyulan güvenin ve psikolojik güçlendirmenin örgütsel vatandaşlık davranışı üzerindeki etkilerini belirlemeye yönelik görgül bir çalışma. Tisk Akademi, 3(5), 100-117.

Baron, R. M., \& Kenny, D. A. (1986). The moderator-mediator variable distinction in social psychological research: Conceptual, strategic, and statistical considerations. Journal of Personality and Social Psychology, 51(6), 11731182.

Boğan, E., \& Dedeoğlu, B. B. (2016). Otel işletmelerinde davranışsal dürüstlük ve iş tatmini arasındaki ilişkide yönetime güvenin aracılık rolü. 16. Ulusal Turizm Kongresi, Çanakkale (473-488).

Bollen, K. A., \& Stine, R. (1990). Direct and indirect effects: Classical and bootstrap estimates of variability. Sociological Methodology, 20(1), 115-140.

Colquitt, J. A., Conlon, D. E., Wesson, M. J., Porter, C. O. L. H., \& Ng, Y. K. (2001). Justice at the millennium: A metaanalytic review of 25 years of organizational justice research. Journal of Applied Psychology, 86(3), 425-445.

Colquitt, J. A., Scott, B. A., \& LePine, J. (2007). Trust, trustworthiness, and trust propensity: A meta-analytic test of their unique relaitonships with risk taing and job performance. Journal of Applied Psychology, 92(4), 909-927.

Creed, W. E. D., \& Miles, R. E. (1996). Trust in organizations: A conceptual framework linking organizational forms, managerial philosophies, and the opportunity costs of controls. içinde R. M. Kramer \& T. R. Tyler (Eds.), Trust in Organizations: Frontiers of Theory and Research (s. 16-38). Thousand Oaks, CA: Sage Publications.

Çavuş, M. F., \& Develi, A. (2015). İnsan kaynakları yönetimi uygulamalarının örgütsel vatandaşlık davranışı üzerindeki etkileri. Tisk Akademi, 10(20), 230-249.

Deluga, R. J. (1995). The relation between trust in the supervisor and subordinate organizational citizenship behavior. Military Psychology, 7(1), 1-16.

Dirks, K. T., \& Ferrin, D. L. (2002). Trust in leadership: Meta-anlaytic findings and implications for research and practice. Journal of Applied Psychology, 87(4), 611-628.

Fritz, M. S., \& MacKinnon, D. P. (2007). Required sample size to detect the mediated effect. Psychological Science, 18, 233-239.

Hair, J. F., Black, W. C., Babin, B J., \& Anderson, R. E. (2014). Multivariate Data Analysis. Pearson International Edition, 7th Edition. US: Pearson Education Limited. 
Hayes, A. F. (2009). Beyond Baron and Kenny: Statistical mediation analysis in the new millennium. Communication Monographs, 76(4), 408-420.

Hayes, A. F. (2018). Introduction to mediation, moderation, and conditional process analysis: A regression-based approach (Second edition). New York, NY: Guilford Press.

Hayes, A. F., \& Scharkow, M. (2013). The relative trustworthiness of inferential tests of the indirect effect in statistical mediation analysis: Does method really matter? Psychological Science, 24(10), 1918-1927.

Hayes, A. F., Preacher, K. J., \& Myers, T. A. (2011). Mediation and the estimation of indirect effects in political communication research. İçinde E. P. Bucy \& R. L. Holbert (Eds.), Sourcebook for political communication research: Methods, measures and analytical techniques (ss. 434-465). New York: Routledge.

Ilies, R., Nahrgang, J., \& Morgeson, F. P. (2007). Leader-member exchange and citizenship behaviors: A meta-analysis. Journal of Applied Psychology, 92(1), 269-277.

Kannan-Narasimhan, R., \& Lawrence, B. S. (2012). Behavioral integrity: How leader referents and trust matter to workplace outcomes. Journal of Business Ethics, 111, 165-178.

Katz, D. (1964). The motivational basis of organizational behavior. Behavioral Science, 9, 131-133.

Klaussner, S. (2012). Trust and leadership: Toward an interactive perspective. Journal of Change Management, 12(4), 417-439.

Lennick, D., \& Kiel, F. (2007). Moral intelligence: Enhancing business performance and leadership success. Upper Saddle River, NJ: Wharton School.

LePine, J. A., \& Van Dyne, L. (2001). Voice and cooperative behavior as contrasting forms of contextual performance: Evidence of differential relationships with Big Five personality characteristics and cognitive ability. Journal of Applied Psychology, 86(2), 326-336.

MacKinnon, D. P., Lockwood, C. M., Hoffman, J. M.,West, S. G., \& Sheets, V. (2002). A comparison of methods to test mediation and other intervening variable effects. Psychological Methods, 7(1), 83-104.

Mayer, R. C., Davis, J. H., \& Schoorman, F. D. (2006). An integrative model of organizational trust. R. M. Kramer (Ed.) İçinde, Organizatioanl Trust: A Reader (ss. 82-108). New York NY: Oxford University Press.

Moorman, R. H., Darnold, T. C., \& Priesemuth, M. (2013). Perceived leader integrity: Supporting the construct validity and utility of a multi-dimensional measure in two samples. The Leadership Quarterly, 24(3), 427-444.

Moorman, R., \& Grover, S. L. (2009). Why does leader integrity matter to followers? An uncertainty management-based explanation. International Journal of Leadership Studies, 5(2), 102-114.

Nielsen, T. M., Hrivnak, G. A., \& Shaw, M. (2009). Organizational citizenship behavior and performance: A meta-analysis of group-level research. Small Group Research, 40, 555-577.

Organ, D. (1988). Organizational citizenship behavior: The good soldier syndrome. Lexington, MA: Lexington books.

Organ, D. W., \& Ryan, K. (1995). A meta-analytic review of attitudinal and dispositional predictors of organizational citizenship behavior. Personnel Psychology, 48(4), 755-802.

Organ, D. W., Podsakoff, P. M., \& MacKenzie, S. B. (2006). Organizational Citizenship Behavior: Its Nature, Antecedents and Consequences. Thousand Oaks, CA: Sage Publications.

Palanski, M. E., \& Yammarino, F. J. (2007). Integrity and leadership: Clearing the conceptual confusion. European Management Journal, 25(3), 171-184.

Piccolo, R. F., Buengeler, C., \& Judge, T. A. (2018). Leadership [IS] organizational citizenship behavior: Review of a selfevident link. İçinde P. M. Podsakoff, S. B. Mackenzie \& N. P. Podsakoff (Eds.), The Oxford Handbook of Organizational Citizenship Behavior (ss. 297-316). New York, NY: Oxford University Press.

Podsakoff, P. M., MacKenzie, S. B., Moorman, R. H., \& Fetter, R. (1990). Transformaitonal leader behaviors and their effects on followers' trust in leader, satisfaction, and organizatiponal citizenship behaviors. The Leadership Quarterly, 1(2), 107-142.

Podsakoff, P. M., MacKenzie, S. B., Paine, J. B., \& Bachrach, D. G. (2000). Organizational citizenship behavior: A critical review of the theoretical and empirical literature and suggestions for future research. Journal of Management, 26(3), 513-563.

Podsakoff, N. P., Whiting, S. W., Podsakoff, P. M., \& Blume, B. D. (2009). Individual- and organizational-level consequences of organizational citizenship behaviors: A metaanalysis. Journal of Applied Psychology, 94, 122141. 
Poon, J. M. L. (2013). Effects of benevolence, integrity, and ability on trust-in-supervisor. Employee Relations, 35(4), 396407.

Preacher, K. J., \& Hayes, A. F. (2008). Contemporary approaches to assessing mediation in communication research. İçinde A. F. Hayes, M. S. Slater \& L. B. Snyder (Eds.), The SAGE Sourcebook of Advanced Data Analysis Methods for Communication Research (ss. 13-54). Thousand Oaks, CA: Sage Publications, Inc.

Rubin, R. S., Bommer, W. H., \& Bachrach, D. G. (2010). Operant leadership and employee citizenship: A question of trust? The Leadership Quarterly, 21(3), 400-408.

Simons, T. (2002). Behavioral integrity: The perceived alignment between managers' words and deeds as a research focus. Organization Science, 13, 18-35.

Simons, T. (2008). The integrity dividend: Leading by power of your word. San Francisco: Jossey-Bass.

Simons, T., \& McLean Parks, J. (2000, August). The sequential impact of behavioral integrity on trust, commitment, discretionary service behavior, customer satisfaction, and profitability. Paper presented at the annual meeting of the Academy of Management, Toronto, Ontario, Canada.

Simons, T., Friedman, R., Liu, L. A., \& McLean Parks, J. (2007). Racial differences in sensitivity to behavioral integrity: Attitudinal consequences, in-group effects, and "trickle down" among Black and non-Black employees. Journal of Applied Psychology, 92(3), 650-665.

Simons, T., Leroy, H., Collewaert, V., \& Masschelein, S. (2015). How leader alignment of words and deeds affects followers: A meta-analysis of behavioral integrity research. Journal of Business Ethics, 132(4), 831-844.

Sosik, J. J., Gentry, W. A., \& Chun, J. U. (2012). The value of virtue in the upper echelons: A multisource examination of executive character strengths and performance. The Leadership Quarterly, 23(3), 367-382.

Spitzmuller, M., Van Dyne, L., \& Ilies, R. (2008). Organizational citizenship behavior: A review and extension of its nomological network. İçinde J. Barling \& C. L. Cooper (Eds.), The SAGE Handbook of Organizational Behavior, Volume 1 Micro Perspectives (ss. 106-123). Thousand Oaks, CA: Sage Publications, Inc.

Wat, D., \& Schaffer, M. A. (2005). Equtiy and relationship quality influences on organizational citizenship behaviors: The mediating role of trust in the supervisor and empowerment. Personnel Review, 34(4), 406-422.

Whitener, E. M., Brodt, S. E., Korsgard, M. A., \& Werner, J. M. (2006). Managers as initiators of trut: An Exchange relationship framework for understanding managerial trustworthy behavior. R. M. Kramer (Ed.) İçinde, Organizational Trust: A Reader (ss. 140-169). New York NY: Oxford University Press.

Whitman, D. S., Van Rooy, D. L., \& Viswesvaran, C. (2010). Satisfaction, citizenship behaviors, and performance in work units: A meta-analysis of collective construct relations. Personnel Psychology, 63, 41-81.

Williams, L. J., \& Anderson, S. E. (1991). Job satisfaction and organizational commitment as predictors of organizational citizenship and in-role behaviors. Journal of Management, 77(3), 601-617.

Wong, Y. T., Ngo, H. Y., \& Wong, C. S. (2003). Antecedents and outcomes of employees' trust in Chinese joint ventures. Asia Pasific Journal of Management, 20(4), 481-499.

Yıldız, S. (2014). Örgütsel adaletin örgütsel vatandaşlık davranışına etkisinde iş tatmininin aracı rolü. Ege Akademik Bakış, 14(2), 199-210.

Zhang, G., Bai, Y., Caza, A., \& Wang L. (2014). Leader integrity and organizational citizenship behavior in China. Management and Organization Review, 10(2), 299-319. 